\title{
AKTIVITAS ANTIFUNGI SARI DAUN PEPAYA (Carica papaya L.) TERHADAP Candida albicans
}

\author{
Siska Nuryanti \\ Fakultas Farmasi, Universitas Muslim Indonesia, Makassar \\ Email : siska.nuryanti@umi.ac.id
}

\begin{abstract}
A research had been done on antifungal activity of papaya leaf ekstract (Carica papaya $L$.) and the aim was to determine the antifungal activity and inhibitory potency. The research was started by screening test using Candida albicans. Results showed that the papayaleaf ekstract inhibited Candida albicans. The research was continued by Minimum Inhibitory Concentration (MIC) test by liquid dilution method in Potato Dekstrosa Broth medium toward, Candida albicans in concentration of MIC 5\%, 10\%, 15\% and $20 \%$. Result showed that papaya leaf ekstract (Carica papaya L.) has antifungal activity wich was indicated by the inhibitory zone diameter in concentration of $10 \%, 15 \%$, and $20 \%$ respectively on Candida albicans.
\end{abstract}

Key words: Antfungal activity, papaya leaf ekstract, Carica papaya L.

\section{PENDAHULUAN}

Indonesia merupakan negara

yang kaya dengan beraneka ragam flora dan fauna. Keanekaragaman ini (terutama tumbuhan) mengundang pehatian banyak orang untuk memilih jalur alternatif dalam pengobatan, mengingat terlalu banyak efek samping dari produk obat-obatan sintetis.

Pepaya tergolong tanaman yang populer dan digemari oleh hampir seluruh penduduk penghuni bumi ini termasuk indonesia. Pemanfaatan tanaman pepaya cukup beragam. Daun Pepaya, bunga, dan buah yang masih mentah dapat dibuat sebagai bahan berbagai ragam sayuran. Dalam pengobatan tradisional, bagian-bagian tanaman pepaya banyak yang digunakan.

Daun papaya muda dapat dipergunakan untuk pengobatan penyakit demam, penambah nafsu makan, keputihan, jerawat, menambah air susu, serta mengobati sakit gigi ${ }^{1}$, daun pepaya juga dapat bermanfaat sebagai antifungi dimana berdasarkan penelitian yang telah dilakukan oleh Ismi Rahmawati yang menyatakan bahwa ekstrak etanol, fraksi n-heksan, dan etil asetat dari daun pepaya 
(Carica papaya L.) memiliki aktivitas antifungi terhadap Candida albicans.

Candida albicans merupakan fungi dimorfik karena kemampuannya untuk tumbuh dalam dua bentuk yang berbeda yaitu sebagai sel tunasyang akan berkembang menjadi blastospora dan menghasilkan kecambah yang akan membentuk hifa semu. Perbedaan bentuk ini tergantung pada faktor eksternal yang mempengaruhinya. Sel ragi (blastospora) berbentuk bulat, lonjong atau bulat lonjong dengan ukuran $2-5 \mu$ x 3-6 $\mu$ hingga $2-5,5 \mu$ x 5-28 $\mu$.

\section{Candida}

albicans

memperbanyak diri dengan membentuk tunas yang akan terus memanjang membentuk hifa semu. Hifa semu terbentuk dengan banyak kelompok blastospora berbentuk bulat atau lonjong di sekitar septum. Morfologi koloni Candida albicans pada medium padat agar sabouraud dekstrosa, umumnya berbentuk bulat dengan permukaan sedikit cembung, halus, licin dan kadang-kadang sedikit berlipat-lipat terutama pada koloni yang telah tua. Umur biakan mempengaruhi besar kecil koloni. Warna koloni putih kekuningan dan berbau asam seperti aroma tape. Candida albicans dapat tumbuh pada variasi $\mathrm{pH}$ yang luas, tetapi pertumbuhannya akan lebih baik pada $\mathrm{pH}$ antara 4,5-6,5. Jamur ini dapat tumbuh dalam perbenihan pada suhu $28^{\circ} \mathrm{C}-37^{\circ} \mathrm{O}{ }^{2}{ }^{2}$

Dalam daun pepaya terkandung senyawa alkaloid, flavonoid, polifenol, saponin, karpain, caricaksantin, violaksantin, dan papain,. Daun pepaya juga mengandung protein tinggi, lemak, vitamin, kalsium (Ca) dan zat besi $(\mathrm{Fe})$ yang berfungsi sebagai pembentukan hemoglobin. ${ }^{3}$

Senyawa-senyawa antifungi umumnya terdapat pada golongan senyawa fenol ${ }^{4}$, flavonoid, saponin dan alkaloid. ${ }^{5}$

Hal inilah yang mendasari timbulnya permasalahan, bagaimana pemanfaatan sari daun pepaya (Carica papaya L.) yang berkhasiat untuk kesehatan dengan melihat pengujian aktivitas sari daun pepaya (Carica papaya L.) sebagai antifungi yang ingin diujikan terhadap beberapa mikroba uji yang merupakan penyebab penyakit.

\section{METODE PENELITIAN}

\section{Alat dan Bahan}

Alat - alat yang digunakan pada pada penelitian ini adalah autoklaf ( Smic Model YX-280B ${ }^{\circledR}$ ), Botol coklat, cawan petri $\left(\right.$ Normax $\left.^{\circledR}\right)$, cotton swab steril, erlenmeyer, gelas kimia, inkubator $\left(\right.$ Memmert $\left.^{\circledR}\right)$, oven 
$\left(\right.$ Fisher $\left.^{\circledR}\right)$, ose bulat, penangas air, tabung, timbangan analitik, spektrofotometer UV, dan vial. Bahanbahan yang digunakan adalah Bahanbahan yang digunakan dalam penelitian ini adalah aquadest, disc blank, biakan murni fungi (Aspergillus niger, Candida albicans, Rhizopus sp), larutan $\mathrm{NaCl}$ fisiologis $0,9 \%$, medium PDA, medium PDB, dan sampel sari daun pepaya.

\section{Prosedur penelitian}

\section{Pengambilan sampel}

Sampel daun pepaya (Carica papaya L.) diperoleh di daerah Samata Kabupaten Gowa Makassar Sulawesi selatan. Pengambilan sampel dilakukan pada pagi hari.

\section{Pengolahan sampel}

Sampel Daun pepaya (Carica papaya L.) dibersihkan dari kotorankotoran yang melekat dengan menggunakan air yang mengalir, dipotong-potong kecil kemudian di Tumbuk, dan di ambil sari daun pepaya dengan cara di peras dan disaring menggunakan kain saring lalu di masukkan kedalam botol steril.

\section{Penyiapan alat dan bahan}

Alat - alat yang digunakan dicuci hingga bersih dengan air bersih, kemudian alat - alat gelas dikeringkan lalu dibungkus dengan kertas dan disterilkan dengan menggunakan oven pada suhu $180^{\circ} \mathrm{C}$ selama 2 jam. Alat alat gelas yang berskala dan tidak tahan terhadap pemanasan dan yang terbuat dari plastik disterilkan dalam autoklaf pada suhu $121^{\circ} \mathrm{C}$ selama 15 menit. Ose disterilkan dengan cara dipijarkan pada lampu spiritus.

\section{Penyiapan mikroba uji}

\section{Peremajaan mikroba uji}

Disiapkan mikroba uji yang berasal dari biakan murni fungi Candida albians, diambil 1 ose lalu diinokulasikan dengan cara digoreskan pada medium Potato Dextrosa Agar (PDA), lalu diinkubasi pada suhu $27^{\circ} \mathrm{C}$ selama $3 \times 24$ jam.

\section{Pembuatan suspensi mikroba uji}

Kultur fungi umur $3 \times 24$ jam yang telah diremajakan dalam medium Potato dextrosa Agar (PDA) disuspensikan dengan $\mathrm{Nacl}$ fisiologis $(\mathrm{NaCl} \quad 0,9 \%)$ kemudian diukur kekeruhannya $75 \%$ T untuk fungi .

\section{Pengujian sampel}

Pengujian konsentrasi hambat minimum (KHM)

Pada uji skrining dengan konsentrasi sampel $5 \%$ positif memperlihatkan tidak adanya pertumbuhan mikroba uji. Kemudian lanjutkan dengan pengujian $\mathrm{KHM}$ dengan membuat konsentrasi untuk masing-masing sampel yaitu $5 \%, 10 \%$, $15 \%, 20 \%$ Setelah itu, disiapkan 
tabung reaksi steril yang kedalamnya dimasukkan medium PDB dicukupkan hingga volume $5 \mathrm{ml}$ kemudian disterilkan dengan autoklaf pada suhu $121^{\circ} \mathrm{C}$ selama 15 menit. Kemudian ke dalam medium PDB yang telah disterilkan dimasukkan masing-masing sampel yang telah dilarutkan sehingga volumenya menjadi $5 \mathrm{ml}$. Setelah itu, kedalam masing-masing tabung reaksi dimasukkan $20 \mu \mathrm{l}$ suspensi fungi lalu dihomogenkan dan di inkubasi pada suhu $27^{\circ} \mathrm{C}$ selama $3 \mathrm{x}$ 24 jam. Kemudian diamati KHMnya yang ditandai dengan kekeruhan pada medium.

\section{Pengujian konsentrasi bunuh minimum (KBM)}

Hasil inkubasi pada uji KHM masing-masing digoreskan pada medium PDA dalam cawan petri dan diinkubasi kembali pada suhu $27{ }^{\circ} \mathrm{C}$ selama $3 \times 24$ jam. Nilai KBM ditunjukkan dengan tidak adanya pertumbuhan fungi pada konsentrasi terendah sampel.

\section{Pengujian secara Difusi Agar}

Medium PDA steril yang telah dicairkan sebanyak $10 \mathrm{ml}$ dituang kedalam cawan petri steril dan dibiarkan memadat. Setelah memadat diapuskan masing-masing mikroba uji ke tiap-tiap cawan petri. kemudian di letakkan 4 disc blank yang telah direndam pada pengenceran sampel dengan konsentrasi $5 \%, 10 \%, 15 \%$, $20 \%$ selama 1 jam, lalu diinkubasi pada suhu $27^{\circ} \mathrm{C}$ selama $3 \times 24$ jam. Suatu sampel digolongkan memiliki aktifitas antifungi jika terbentuk zona bening atau disebut juga zona hambatan disekitar disk sampel.

\section{HASIL PENELITIAN}

\section{Pengujian Konsentrasi Hambat Minimum (KHM)}

Penentuan nilai KHM berdasarkan kekeruhan dari larutan uji. Konsentrasi terkecil yang tidak menunjukkan kekeruhan pada larutan uji merupakan nilai KHM. Pada pengujian KHM sari daun papaya (Carica papaya L.) di peroleh nilai KHM 15\% untuk Candida albicans. 
Tabel 1. Hasil Uji Konsentrasi Hambat Minimum (KHM) Sari Daun Pepaya (Carica papaya L.) Terhadap Candida albicans

\begin{tabular}{|c|c|c|c|c|c|}
\hline \multirow{2}{*}{ NO } & \multirow{2}{*}{ Perlakuan } & \multicolumn{4}{|c|}{$\begin{array}{c}\text { Konsentrasi Sari Daun Pepaya } \\
\text { (Carica papaya L.) (\%) }\end{array}$} \\
\hline & & $5 \%$ & $10 \%$ & $15 \%$ & $20 \%$ \\
\hline 1 & Candida albicans & - & - & + & + \\
\hline 2 & Kontrol medium + sampel & + & + & + & + \\
\hline
\end{tabular}

Keterangan :

$+\quad=$ Jernih

$=$ Keruh

Pengujian Konsentrasi Bunuh

Minimum (KBM)

Untuk pengujian KBM dilakukan

dengan menggoreskan hasil KHM pada medium padat. Diperoleh nilai KBM sari daun papaya (Carica papaya

L.) untuk Fungi Candida albicans

Tabel 2. Hasil Uji Konsentrasi Bunuh Minimum (KBM) Sari Daun Pepaya (Carica papaya L.) Terhadap Candida albicans

\begin{tabular}{cccccc}
\hline \multirow{2}{*}{ NO } & Perlakuan & \multicolumn{4}{c}{$\begin{array}{c}\text { Konsentrasi Sari Daun Pepaya } \\
\text { (Carica papaya L.) (\%) }\end{array}$} \\
\cline { 3 - 6 } & & $5 \%$ & $10 \%$ & $15 \%$ & $20 \%$ \\
\hline 1 & Candida albicans & - & - & + & + \\
2 & Kontrol medium + sampel & + & + & + & + \\
\hline
\end{tabular}

\section{Pengujian Difusi Agar}

Hasil uji aktivitas difusi agar sari daun papaya (Carica papaya L.) terhadap beberapa mikroba uji yaitu

Tabel 3. Pengukkuran Diameter Zona Hambat
Aspergillus niger, Candida albicans, dan Rhizopus sp menghasilkan zona hambatan yang berbeda.

\begin{tabular}{ccccc}
\hline \multirow{2}{*}{ Perlakuan } & \multicolumn{4}{c}{ Diameter Zona Hambat $(\mathbf{m m})$} \\
\cline { 2 - 5 } & $\mathbf{5 \%}$ & $\mathbf{1 0 \%}$ & $\mathbf{1 5 \%}$ & $\mathbf{2 0} \%$ \\
\hline Replikasi 1 & 0 & 0 & 11,5 & 13 \\
Replikasi 2 & 0 & 0 & 10,5 & 12 \\
Jumlah & 0 & 0 & 22 & 25 \\
Rata-rata & 0 & 0 & 11 & 12,5 \\
\hline
\end{tabular}




\section{PEMBAHASAN}

Tanaman pepaya (Carica papaya L.) merupakan tanaman herbal yang hampir seluruh bagian tanaman yaitu daun, buah, biji, batang banyak digunakan oleh masyarakat untuk tujuan pengobatan herbal yang merupakan tradisi dan budaya yang sudah lama di Indonesia. Manfaat tanaman herbal pepaya (Carica papaya L.) digunakan sebagai obat herbal tradisional untuk mengobati berbagai macam penyakit.

Daun pepaya (Carica papaya L.) merupakan salah satu tanaman yang dapat digunakan sebagai antifungi, Adapun kandungan kimia yang dimiliki oleh daun pepaya (Carica papaya L.) adalah alkaloid, fenol, flavonoid, dan saponin.

Penelitian tentang khasiat antifungi dari daun pepaya (Carica papaya L.) masih kurang dilakukan. Dimana pada penelitian sebelumnya yang dilakukan oleh Ismi Rahmawati dengan menggunakan sampel ekstrak etanol, fraksi n-Heksan, dan etil asetat dari daun pepaya (Carica papaya L.) memiliki aktivitas antifungi terhadap Candida albicans. Oleh karena itu, maka dilakukan pengujian Uji Aktivitas Antifungi dari sari daun pepaya (Carica papaya L.) yang akan di ujikan terhadap berberapa mikroba uji.

Ada beberapa pengujian aktivitas antifungi yaitu dengan menggunakan metode dilusi, difusi, atau uji bioautografi. Metode dilusi digunakan untuk menentukan nilai hambat minimum dari mikroba uji dengan menggunakan medium cair dan padat, sedangkan metode difusi digunakan untuk melihat daerah hambatan dari mikroba yang akan diuji dengan menggunakan medium padat.

Pada penelitian ini digunakan 3 mikroba uji jenis fungi. Pemilihan mikroba uji jenis fungi tersebut didasarkan dari pengujian yang akan dilakukan yaitu uji aktivitas antifungi.serta sifat-sifatnya yang patogenik. Candida albicans merupakan fungi yang bersifat patogenik penyebab candidiasis atau vaginitis. Aspergillus niger merupakan fungi yang bersifat patogenik penyebab telinga otomykosis dan Rhizopus $s p$ merupakan fungi yang dapat tumbuh pada makanan sehingga dapat menyebabkan keracunan serta penyakit infeksi craniofacial

Medium Potato Dekstrosa Agar (PDA) merupakan medium agar yang digunakan pada metode dilusi padat 
dan untuk menumbuhkan biakan mikroba uji. Sedangkan medium Potato Dekstrosa Broth (PDB) merupakan medium cair yang digunakan pada pengujian Konsentrasi Hambat Minimum (KHM). Medium Potato Dekstrosa Agar (PDA) dan Potato Dekstrosa Broth (PDB) ini berisi Kentang sebagai sumber protein dan glukosa sebagai sumber karbohidrat yang diketahui dapat menunjang pertumbuhan fungi.

Mikroba uji yang akan digunakan terlebih dahulu diukur transmitannya pada $75 \% \mathrm{~T}$ yang dapat diukur dengan spektrofotometer dimana cahaya bergelombang panjang $580 \mathrm{~nm}$ melalui suspensi mikroba dengan prinsip penyerapan cahaya merupakan fungsi konsentrasi molekul yang menyerap atau dapat juga dengan menggunakan standar Mc Farland berdasarkan kekeruhannya.

Metode Dilusi merupakan suatu cara yang digunakan untuk menentukan Konsentrasi Hambat Minimum (KHM) dan Konsentrasi Bunuh Minimum (KBM).

Pengujian Konsentrasi Hambat Minimum (KHM) adalah konsentrasi minimal dari suatu zat yang akan menghambat pertumbuhan suatu mikroorganisme. Pada pengujian ini digunakan konsentrasi 5\%, 10\%, 15\%, dan $20 \%$, antara sampel dan medium Potato Dekstrosa Broth (PDB). Dimana medium Potato Dekstrosa Broth (PDB) ini merupakan medium cair yang digunakan pada pengujian Konsentrasi Hambat Minimum (KHM). Kegunaan dari Uji Konsentrasi Hambat Minimum (KHM) ini adalah untuk mengetahui konsentrasi terendah dari suatu sampel dalam menghambat pertumbuhan mikroba uji. Dimana semakin keruh larutan uji maka semakin kecil penghambatan terhadap mikroba uji yang terdapat pada larutan uji dan sebaliknya dimana semakin jernih larutan uji maka semakin besar penghambatan terhadap mikroba uji yang terdapat pada larutan uji.

Dari hasil pengujian Konsentrasi Hambat Minimum (KHM) di dapatkan nilai Konsentrasi Hambat Minimum (KHM) untuk mikroba uji candida albicans terdapat pada konsentrasi $15 \%$.

Pengujian dilanjutkan dengan uji Konsentrasi Bunuh Minimum (KBM) yaitu konsentrasi minimal dari suatu zat yang membunuh (KBM) dimana pengujian ini dilakukan dengan menggoreskan masing-masing hasil inkubasi pada uji KHM pada medium Potato Dekstrosa Agar (PDA) dalam cawan petri dan diinkubasi kembali pada suhu $27^{\circ} \mathrm{C}$ selama $3 \times 24$ jam. 
Nilai Konsentrasi Bunuh Minimum (KBM) ditunjukkan dengan tidak adanya pertumbuhan fungi pada konsentrasi terendah sampel.

Berdasarkan hasil pengujian yang telah dilakukan maka, diperoleh nilai Konsentrasi Bunuh Minimum (KBM) untuk Candida albicans terdapat pada konsentrasi $15 \%$

Selanjutnya pengujian aktivitas antifungi dengan metode difusi agar. Dimana metode difusi agar adalah metode yang digunakan untuk melihat aktivitas dari suatu sampel terhadap mikroba uji dengan melihat adanya zona bening yang terbentuk. Kelebihan dari metode difusi agar ini yaitu kita dapat mengukur zona hambatan yang terbentuk. Zona hambatan adalah zona bening yang terbentuk disekeliling disc blank. Dimana disc blank ini mengeluarkan zat yang dapat menghambat pertumbuhan mikroba. Pemilihan penggunaan disc blank karena proses difusinya cepat, mudah dalam pengerjaan, sampel yang digunakan lebih sedikit.

Untuk menumbuhkan mikroba uji digunakan metode swab yaitu suatu teknik menumbuhkan mikroorganisme di dalam media agar dengan cara mengapuskan suspensi mikroba di atas media agar yang telah memadat dengan menggunakan cotton swab steril. Adapun kelebihan dari metode swab ini yaitu mikroba uji yang disebarkan diatas medium merata dan memungkinkan mikroba tumbuh pada permukaan medium.

Dari hasil penelitian aktifitas antifungi sari daun pepaya (Carica papaya L.) terhadap mikroba uji dengan menggunakan metode difusi agar dengan variasi konsentrasi $5 \%$, $10 \%, 15 \%$, dan $20 \%$, diperoleh hasil dengan terbentuknya zona hambat disekitar disc blank untuk konsentrasi $5 \%$ ialah $0 \mathrm{~mm}$, konsentrasi $10 \%$ ialah $0 \mathrm{~mm}$, konsentrasi $15 \%$ ialah $11 \mathrm{~mm}$, konsentrasi $20 \%$ ialah $12,5 \mathrm{~mm}$. Terbentuknya zona hambat di sekitar disc blank dikarenakan adanya kandungan senyawa aktif antifungi pada sampel daun papaya (Carica papaya L.) yang menghambat pertumbuhan fungi yang ada di sekitar disc blank.

\section{KESIMPULAN :}

Berdasarkan penelitian yang telah dilakukan terhadap Sari daun papaya (Carica papaya L.) maka dapat disimpulkan bahwa sari daun pepaya (Carica papaya L.) dapat menghambat pertumbuhan mikroba uji Candida albicans. Sari daun pepaya (Carica papaya.L) dapat memberikan aktivitas antifungi terhadap Candida albicans 
paling besar pada konsentrasi 20\% dengan besar zona hambat $12,5 \mathrm{~mm}$

\section{DAFTAR PUSTAKA}

1. Johanis FR. Uji Aktivitas Ekstrak Daun Pepaya (Carica papaya. LINN) Sebagai Antimalaria Agen. Papua : Fakultas Keguruan dan Ilmu Pendidikan Universitas Pattimura; 2010.

2. Riana C. Karakteristik Candida albicans. Cermin Dunia Kedokteran 2006;151. Infeksi pada Kehamilan (online),(http://www.kalbe.co.id/pdf) (diakses 20 september 2016).
3. Tietze HW. Tempi Pepaya Buah Terapi Makanan yang Aman dan Murah. Jakarta : Prestasi Pustaka Raya; 1997.

4. Harliana D. Aktivitas Antijamur Ekstrak Rimpang Temu Glenyeh (Skripsi). Surakarta : Fakultas MIPA UNS;2006.

5. Padmawinata K. Kandungan Organik Tumbuhan Tinggi. Edisi Keenam. Bandung: ITB; 1995 Terjemahan: The Organic Constituents of Hegher Planks. Robinson, T. Department of Biochemistry University of Massachusetts Amherst; 1991. 